\title{
JESUS’ RESURRECTION AND COLLECTIVE HALLUCINATIONS
}

\author{
Jake O'Connell
}

\begin{abstract}
Summary
This study is divided into two parts. Part I examines modern accounts of collective religious visions. Five factors make it very likely that such visions are collective hallucinations. Part II examines whether the same is true of Jesus' resurrection appearances. The evidence indicates that if the resurrection appearances were collective hallucinations, hallucinations of glorious appearances of Jesus would have occurred alongside hallucinations of non-glorious appearances. Since the Gospels relate only non-glorious appearances of Jesus, hallucinations can only be maintained as an explanation if the original tradition of glorious/non-glorious appearances was changed to a tradition of purely non-glorious appearances. However, there are strong reasons to believe that the early church would have preserved, not eliminated, traditions of glorious appearances, had such existed. The lack of glorious appearances in the Gospels is therefore an indicator that the appearances were originally non-glorious and thus not hallucinations. Thus, collective hallucinations provide an inadequate explanation for the resurrection appearances.
\end{abstract}

\section{Collective Religious Visions}

It has long been argued that Jesus' resurrection appearances can be explained as hallucinations (or subjective visions). This suggestion was popularised in the critical era by David Strauss ${ }^{1}$ and has won an

1 David Friedrich Strauss, The Life of Jesus Critically Examined (London: G Allen, 1913): 739-44. 
increasing number of adherents in recent years. ${ }^{2}$ However, the hypothesis has not gone uncriticised, with the strongest argument against it being that the fact of group resurrection appearances is incompatible with hallucinations because group hallucinations are impossible. ${ }^{3}$ This argument carries a considerable amount of weight, as

2 On the growing popularity of this hypothesis, see Gary R. Habermas, 'Explaining Away Jesus' Resurrection: The Recent Revival of Hallucination Theories', Christian Research Journal 23.4 (2001): 26-31, 47-49; Gary R. Habermas, 'Mapping the Recent Trend toward the Bodily Resurrection Appearances of Jesus in Light of Other Prominent Critical Positions' in The Resurrection of Jesus: John Dominic Crossan and N.T. Wright in Dialogue, ed. Robert B. Stewart (Minneapolis: Fortress, 2006): 83-84. Proponents of the hallucination hypothesis include: Vernon Shelby McCasland, 'Peter's Vision of the Risen Christ', JBL 47 (1928): 41-59; Maurice Goguel, The Birth of Christianity (London: George Allen \& Unwin, 1953): 74-86; H.C. Snape, 'After the Crucifixion or "The Great Forty Days", Numen 17 (1970): 188-99; Margaret E. Thrall 'Resurrection Traditions and Christian Apologetic', Thomist 43 (1979): 204-205, 209211; Gerd Ludemann, The Resurrection of Jesus: History, Experience, Theology (Minneapolis: Fortress, 1994): 106-107, 174-75, 180; Robert M. Price, Beyond Born Again: Towards Evangelical Maturity (Upper Montclair, New Jersey: Apocryphal, 1993): 81-84 (online version: <http://www.infidels.org/library/modern/robert price/ beyond_born_again/notes.html $>$ [accessed 26 September 2007]); John Dominic Crossan, 'Dialogue' in Will the Real Jesus Please Stand Up? A Debate Between William Lane Craig and John Dominic Crossan, ed. Paul Copan (Grand Rapids, Michigan: Baker, 1998): 63-65 (although Crossan rejects the term 'hallucination', it is clear he believes the appearances were non-veridical visions); Jack A. Kent, The Psychological Origins of the Resurrection Myth (London: Open Gate, 1999): 27-62; Michael Goulder, 'The Explanatory Power of Conversion-Visions' in Jesus' Resurrection: Fact or Figment? A Debate Between William Lane Craig and Gerd Ludemann, ed. Paul Copan (Downers Grove, IL: Intervarsity, 2000): 86-103; Richard C. Carrier, 'The Spiritual Body of Christ and the Legend of the Empty Tomb' in The Empty Tomb: Jesus beyond the Grave, eds. Robert M. Price and Jeffrey Jay Lowder (Amherst, New York: Prometheus, 2005): 184-88; Antony Flew, 'The Dialogue' in Resurrected? An Atheist \& Theist Dialogue, ed. John F. Ankerberg (Lanham: Rowman \& Littlefield, 2005): 8-12, 30-32; Keith Parsons, 'Peter Kreeft and Ronald Tacelli on the Hallucination Theory' in The Empty Tomb: Jesus beyond the Grave, eds. Robert M. Price and Jeffrey Jay Lowder (Amherst, New York: Prometheus, 2005): 433-51; Bart D. Ehrman in Bart D. Ehrman and William Lane Craig, 'Is There Historical Evidence for the Resurrection of Jesus: A Debate Between William Lane Craig and Bart D. Ehrman' (public debate; College of the Holy Cross: Worcester, MA, US, 28 March 2006-transcript available at: <http://www.holycross.edu/departments/crec/ website/resurrdebate.htm $>$ [accessed 26 September 2007]).

3 See Peter Kreeft and Ronald K. Tacelli, Handbook of Christian Apologetics: Hundreds of Answers to Crucial Questions (Downer's Grove: Intervarsity, 1994): 18687; Stephen T. Davis, Risen Indeed: Making Sense of the Resurrection (Grand Rapids, MI: Eerdmans, 1993): 179; Gary R. Habermas and Michael R. Licona, The Case for the Resurrection of Jesus (Grand Rapids: Michigan, 2004): 106-107. Habermas and Licona (Case, 303) give the following quotation from clinical psychologist Gary Collins on the supposed impossibility of collective hallucinations: 'Hallucinations are individual occurrences. By their very nature only one person can see any given hallucination at a time. They certainly are not something which can be seen by a group of people. Neither is it possible that one person could somehow induce a hallucination 
both of its premises appear well-supported. That group resurrection appearances did occur is firmly established by the pre-Pauline formula of 1 Corinthians 15:3-8, and the suggestion that an entire group of people could suddenly burst into a fit of simultaneous hallucinations seems, on the face of it, psychologically unfeasible. Yet, when accounts of modern-day religious visions are examined, it becomes clear that there actually are well-documented cases of group religious visions which possess characteristics indicating that these visions are very likely hallucinatory. Recognising that religiously inspired group hallucinations do occur requires that the hallucination hypothesis can no longer be dismissed by appealing to the impossibility of group hallucinations. If a satisfactory argument against the hallucination hypothesis is to be made, that argument must take into account the fact of collective hallucinations.

\subsection{Defining Terms}

Before beginning, it is essential to define certain key terms involved in the discussion, because these words are often subject to fluctuating definitions. The terms under discussion are: delusion, collective delusion, illusion, collective illusion, peridolia, legend, fraud, hallucination, subjective vision, and objective extraordinary event. A delusion is a false belief; a belief not in accordance with reality. A collective delusion is a false belief shared by two or more people. An illusion is the misperception of actual external stimuli, when that misperception may be attributed to an ordinary malfunction of the senses (e.g. I see a lamp out of the corner of my eye and temporarily mistake it for a person.) A collective illusion is such a misperception shared by two or more people. Peridolia is misinterpreting a vague stimulus as something clear and distinct. A legend is a purported historical event the sources in support of which are insufficient to establish that any actual historical event took place. Fraud is deliberate deception. A hallucination is a) a sensory perception in the absence of external stimuli-the perception of an object which does not exist, or b) the misperception of actual external stimuli when that misperception can only be attributed to an extraordinary malfunction of the senses (e.g. I see a lamp, which I am looking straight at, jump ten feet in the

in somebody else. Since a hallucination exists only in this objective, personal sense, it is obvious that others cannot witness it'. 
air, spin around and begin speaking to me.) $)^{4}$ A subjective vision is synonymous with a hallucination. ${ }^{5}$ A collective hallucination or collective subjective vision is a hallucination shared by two or more people. This does not necessarily mean that the two people are experiencing precisely the same hallucination. A situation in which two or more people are experiencing similar hallucinations simultaneously may also be regarded as a collective hallucination. An objective extraordinary event (OEE) is a seemingly impossible event which does nonetheless occur in objective reality.

The intent of the first part of this article is to show that collective hallucinations have occurred during modern times. However, the literature that has attempted to identify parallels to the group resurrection appearances often considers as candidates for hallucinations, phenomena which should actually be classified as delusion, illusion, peridolia, legend, or fraud. This confusion requires that some pruning be done before beginning. Before looking at those events for which collective hallucination or OEE are the only alternatives, we need to look at the types of events which are said to be one or the other, when in fact they require a different explanation. It will also be helpful to note in passing why these other types of phenomena are clearly not satisfactory parallels to the resurrection appearances, and thus why hallucination is the only one among these

4 The distinction I draw between illusions and type-B hallucinations, since it is one of degree, may not seem satisfactory. I confess to wanting to give a firmer distinction, but I cannot think of how to do so. I consulted with Leonard Doerfler, chair of the psychology graduate program at Assumption College, who was only able to suggest that many psychologists would argue that abnormal behaviour in general is not different in kind from normal behaviour, but only differs in degree - that is, abnormal behaviour is an exaggeration of normal behaviour. On this understanding, the difficulty in distinguishing between ordinary misperceptions and extraordinary ones may just be reflective of the difficulty in distinguishing between normal and abnormal behaviour. But even if it is difficult to express the reason in words, the fact is that seeing a lamp jumping and spinning, and hearing it talk, seems like a fundamentally different experience than thinking for a moment that a lamp which you see out of the corner of your eye is a person. The former seems like an extraordinary occurrence which does not belong alongside the latter, but belongs alongside the phenomenon of a sensory perception with no external stimulus.

5 I have, for the most part, preferred the term 'hallucination' to 'subjective vision' in this essay, since 'hallucination' is the term used by psychologists. It should also be noted from the beginning, that the popular notion that hallucinations are confined to the mentally ill and drug users, is completely inaccurate. Hallucinations occur to normal people for a variety of reasons: see James Robert Brasic, 'Hallucinations', Perceptual and Motor Skills 86 (1998): 851-78. 
phenomena which deserves serious consideration as an explanation for the appearances.

Before discussing the terms above in relation to religious phenomena, it may clarify matters to discuss them in relation to nonreligious phenomena. An example of a delusion is the belief that the FBI is coming after you, when this is in fact not the case; a collective delusion is this belief shared by two or more people. Staring at a lamp for a prolonged period of time and then seeing the lamp move slightly when it has not, is an illusion; a collective illusion is this event experienced by two or more people. Believing a cloud to look like a monster is peridolia. The stories of Robin Hood or of King Arthur are legends. Seeing an elephant which is able to appear and disappear in an instant, when none exists, is a hallucination or subjective vision according to the first sense. Two or more people seeing such an elephant simultaneously (though not necessarily perceiving the elephant in the exact same way) is a collective hallucination. Staring at a lamp for a long period of time and then seeing the lamp make a substantial movement - for example seeing it jump five feet into the air and come down-when no such movement has occurred, is a hallucination according to the second sense. An objective extraordinary event is the actual occurrence of an appearing and disappearing elephant, or a lamp that actually does jump up and down of its own accord.

What kinds of events have been mistakenly considered collective hallucinations? Michael Goulder, whose argument for the hallucinatory nature of the resurrection appearances seems plausible as he explains the individual appearances, becomes strained when he goes looking for parallels to the group appearances. ${ }^{6} \mathrm{He}$ appeals to the proliferation of false Bigfoot reports following the release of a Bigfoot movie as analogous to what happened with the resurrection appearances. ${ }^{7}$ However, no one explains Bigfoot sightings as collective hallucinations, but rather as a matter of, for example, misidentifying an actual animal (such as a bear), seeing large footprints and mistaking them for Bigfoot's, or sometimes outright hoaxing. ${ }^{8}$ The belief in Bigfoot was, in this case, clearly a collective delusion, not a collective

\footnotetext{
6 Goulder, 'Conversion-Visions', 87-96.

7 Goulder, 'Conversion-Visions', 96-97.

8 See further: Craig, 'Closing Response' in Jesus' Resurrection, 188-90.
} 
hallucination. A delusion is only a false belief, and since the resurrection appearances involved not just the belief that Jesus rose from the dead, but claims of some sort of visual phenomenon, ${ }^{9}$ they clearly cannot be considered mere delusions.

The movements that a statue of Mary in Ballinspittle, Ireland displayed during the mid-1980s provide an example of an illusion. The statue was supposed to supernaturally sway back and forth, but a team of psychologists investigating the situation explained it as an optical illusion resulting from staring at a brightly lit object (the statue) against a dark background (the statue was only observed to move at night). ${ }^{10}$ An eyewitness recounts how he saw another brightly lit object (a telephone pole) move after staring at that, and moving his head back and forth. ${ }^{11}$ It is hardly likely that on at least six separate occasions, numerous individuals - including in one case a group of over 500 and in another an individual who was adamantly opposed to the Christian movement (Paul), based on prolonged staring or trickery of the lighting, mistook a lamp or tree or some other such object for Jesus.

Peridolia has produced a great many supposed miracles seen by large groups of people, which are not actually miracles, but which are not collective hallucinations either. Examples have included: a grilled cheese sandwich that looked like Mary, a spot under a bridge that looked like Mary, and a tortilla that looked like Jesus. ${ }^{12}$ There is nothing miraculous about such manifestations; they come about as a result of the same tendency in humans to see monsters, ships, and all sorts of other things in the clouds. But these are not collective hallucinations either; and the absurdity of suggesting that the belief in Jesus' resurrection might have originated as a result of the disciples

9 As will be discussed in greater detail below, I do not in this paper assume the reliability of the Gospels' resurrection narratives. However, I do assume the reliability of 1 Cor. 15:3-8 which attests to appearances to Peter, the Twelve, the 500, James, 'all the apostles', and Paul. On the reliability of this material, see William Lane Craig, Assessing the New Testament Evidence for the Historicity of the Resurrection of Jesus (rev. edn; Lewiston: Edwin Mellen, 2002): 3-62.

10 Peter Kellner, 'Did Mary's Statue Really Move?' in Seeing is Believing: Moving Statues in Ireland, ed. Colm Toibin (Laois, Ireland: Pilgrim, 1985): 29-32, esp. 31.

11 Kellner, 'Statue', 31.

12 On the grilled cheese sandwich: “"Virgin Mary” Toast Fetches \$28,000' at <http:// news.bbc.co.uk/2/hi/americas/4034787.stm> [accessed 26 September 2007]; the spot on the bridge: 'Image on Moline Bridge Described as Mary' at <http://www. freerepublic.com/focus/f-religion/1605625/posts $>$ [accessed 26 September 2007]; the tortilla: 'Shrine of the Miracle Tortilla' at <http://www.roadsideamerica.com/attract/ NMLAKtortilla.html $>$ [accessed 26 September 2007]. 
looking at food or bridges and thinking they saw objects that looked like Jesus in them seems obvious.

Sometimes, an event need not be classified as a hallucination or an OEE, because it need not be classified as an event at all; there is insufficient evidence to establish that it actually happened. The angel of Mons, cited as an example of a collective hallucination by Keith Parsons, ${ }^{13}$ is such a case. There is insufficient evidence to indicate that this alleged being was ever seen simultaneously by two or more people. ${ }^{14}$ However, the pre-Pauline material of 1 Corinthians 15:3-8, which surely dates to within years of the resurrection, and is nearly universally regarded as summarising extremely early material, ensures that the appearances enumerated there cannot be legendary.

Finally, numerous cases exist of supposed weeping and bleeding icons whose miraculous abilities are actually the result of deliberate hoax. ${ }^{15}$ Once again, these are neither OEEs nor hallucinations, but deliberate fraud. And the hypothesis current in Matthew's day (Matthew 28:15) that the disciples stole the body and lied about the resurrection appearances, is justly rejected by almost everyone today. The most basic reason for this consensus is the fact that the disciples were willing to be persecuted for their beliefs, which therefore allows us to be certain that their proclamation was honest, even if we cannot be certain on that ground alone that it was true.

However, these explanations cannot account for all the data. A fair number of well-attested cases do exist which must be explained as either collective hallucinations or OEEs.

\subsection{Cases}

Case 1 Patrick Walker: Covenanter historian Patrick Walker relates a spectacular vision. ${ }^{16}$ Walker tells us that in the year 1686, 'many

13 Parsons, 'Peter Kreeft', 436.

14 See David Clarke, Angel of Mons: Phantom Soldiers and Ghostly Guardians (Chichester, West Sussex: Wiley, 2004): 229-46.

15 See e.g.: 'Church Declares Weeping Virgin Statue a Hoax and Cashes the Missing Donations' at: http://www.smh.com.au/articles/2004/08/05/1091557996497.html? from=storylhs [accessed 26 September 2007]. And "Bleeding, Weeping" Virgin Mary a Hoax: Archbishop' at http://www.smh.com.au/articles/2004/07/29/1091080366746. html? from=storylhs [accessed 26 September 2007].

16 Patrick Walker, Biographia Presbyteriana, (vol. 1; Edinburgh: D. Speare, West Register Street; and J. Stevenson, Prince Street, 1827): 32-33. Available on the CDRom: Reformation Bookshelf Vol. \#30: Reformation History, Martyrs, etc. (Edmonton, Alberta Canada: Still Waters Revival Books, 2002). 
people gathered together for several afternoons' and saw 'Showers of Bonnets, Hats, Guns, and Swords, which covered the Trees and Ground, Companies of Men in Arms marching in order, upon the Waterside, Companies meeting Companies, going all through other, through other, and then all falling to the ground and disappearing; and other Companies immediately appearing the same way.' ${ }^{17} \mathrm{He}$ states further that one of those present was at first unable to see the vision and referred to those who did see it as 'A Pack of damn'd witches and warlocks'. ${ }^{18}$ Yet 'immediately' the man began to see the vision and declared it was 'discernible to all that is not Stone-blind'. ${ }^{19}$ This is indeed a phenomenal occurrence, and since it dates from the seventeenth century, one may be tempted to dismiss it as a legend. However, this may not be done, as Walker tells us he himself was present for three afternoons, and so is an eyewitness. ${ }^{20}$ Moreover, Walker relates another curious fact: he writes that approximately twothirds of the people present saw the vision, while the other thirdhimself included - did not. ${ }^{21}$ If Walker's account was a lie, it would be extraordinarily strange for him to invent the idea that some present did not see the vision as well as to exclude himself from it. His honesty is further demonstrated by his admission that he does not know what to make of the experience: 'I have been at a Loss ever since, what to make of this last'. ${ }^{22}$ Thus fraud, legend, delusion, and peridolia are clearly untenable explanations, and the specificity and variety of what was seen is not consistent with those present having misperceived an ordinary object or objects (illusion). Hence we are left with collective hallucination or OEE as our only alternatives.

Case 2 Moving Statue: For the second case there also exists surviving eyewitness testimony. ${ }^{23}$ On 20 March 1893, Father John McHale took a group of about 70-80 boarding school boys on a picnic in Melleha, Malta in which was located a statue of the Virgin Mary rumoured to move. After arriving at their destination, Father McHale took the students to the cave where the statue was located. As Father McHale

\footnotetext{
17 Walker, Biographia, 32.

18 Walker, Biographia, 33.

19 Walker, Biographia, 33.

20 Walker, Biographia, 32.

21 Walker, Biographia, 32.

22 Walker, Biographia, 33.

23 The following summarises the account in Herbert Thurston, 'Limpias and the Problem of Collective Hallucinations', The Month 136 (1920): 387-98, 533-41.
} 
and the boys were looking at the statue, he asked one of the boys which hand was supposed to move. He was told it was the right hand, which he then looked at, at first seeing nothing, but then:

... almost immediately I was startled by seeing the little finger moving gently backwards. This was followed by the next two fingers, then by the forefinger, and last of all by the thumb. When the fingers had assumed a very graceful position, the whole hand moved gently upwards some ten or twelve inches, came slowly down again and ended by forming a beautiful cross. The fingers then resumed their original hooklike position, and after a pause of a few moments the gesture was again repeated. ${ }^{24}$

Father McHale says the boys with him saw the action too, shouting 'A miracle! A miracle!'25 Father John Gordon, who was present for the journey but had until now remained at the entrance of the cave, came over. He too, saw the hand moving and 'tried several positions' ${ }^{26}$ while still seeing the hand move. In a further experiment:

Fearing lest it might be his own head that was moving, he stood near to the wall, leaning up against it for support, and fixed his eyes on one of the cross-bars of the railing. He then distinctly saw the hand rise above the bar and slowly descend below it. To prevent my own head from moving I tightly squeezed it between two of the bars of the railing, and I can vouch for the movement being precisely the same. ${ }^{27}$

Father McHale says the movement of the hand was not uniform but was seen in a number of different ways. He returned a second time with another group of boys, and this time the statue did not move. But on returning a third time the statue was seen to move again. Although Father McHale is the only one to provide a detailed account, at least three other testimonies to the event are in existence.

Although, Father McHale has provided the only detailed written account still extant, at least three other witnesses have testified to the event. Thurston personally spoke to one of the witnesses, and had at one time a letter from one of the others (this letter was subsequently lost). Thurston also reproduces the important testimony of Marquis Testaferrata Bonici. He testifies that while Father McHale and 'many' of the boys did see the statue move, he himself did not. ${ }^{28}$ His statement

24 Thurston, 'Limpias', 392.

25 Thurston, 'Limpias', 392.

26 Thurston, 'Limpias', 392.

27 Thurston, 'Limpias', 392.

28 Thurston, 'Limpias', 398. 
that 'many' of the boys saw the statue move, clearly implies that there were others present besides him who saw nothing as well.

Case 3 Eucharist: On 20 April 1903, in San Martin de Manzaneda, Father P. Mariscal was preaching on a text from Isaiah regarding contrition and the forgiveness of Christ. ${ }^{29}$ The Eucharist was placed on display as a symbol of Christ's forgiveness. During the sermon, miracles were seen to take place in the Eucharist. Different people beheld different types of miracles. Some saw the Eucharist disappear, to be replaced by the child Jesus with his arms outstretched. Others saw Jesus' heart bleeding. Some saw him holding his hand to stop the bleeding. One person saw the arms outstretched as if on a cross. Others saw the monstrance mysteriously illuminated. As with the other cases, some present saw nothing at all. The local bishop, Vicente Alonso Salgado, took testimonies, from which, it appears, the information provided by Christian is drawn.

Case 4 Marian Apparition: On 22 March 1888, ${ }^{30}$ in Bojano, Italy, two women, Fabiana Cecchino and Serafina Giovanna Valentino, after having gone out to look for some lost sheep, returned home 'crying, sobbing, trembling, and terrified'. ${ }^{31}$ When asked what had disturbed them, they claimed that they had seen a light coming from some fissures in the rocks. On approaching the spot they saw the image of the Addolorata 'a lady, young, very beautiful, pale, with dishevelled hair, and bleeding from the wounds received from seven swords'. ${ }^{32}$ Soon it was reported that a child and an 'avowed heretic' had also seen similar apparitions. ${ }^{33}$ After that, large crowds began to visit the place. In 1889, the bishop of Bojano undertook an investigation, with the results being reported to the pope. He reports that on numerous days hundreds of people gathered at the place, and that many of them did see apparitions. He testifies that he himself saw the Virgin as did the vicar general of the diocese, the archpriest of the cathedral, and 'a very large number of other persons whose names are recorded in the official

29 The following summarises the account in William A. Christian Jr, Moving Crucifixes in Modern Spain (Princeton, New Jersey: Princeton University Press, 1992): 48-50.

30 The following summarises the account in William J. Walsh, The Apparitions and Shrines of Heaven's Bright Queen: In Legend, Poetry and History from the Earliest Ages to the Present Time (vol. 4; New York: T.J. Carey Company, 1904): 173-79.

31 Walsh, Apparitions, 173.

32 Walsh, Apparitions, 173.

33 Walsh, Apparitions, 174. 
report' ${ }^{34}$ Walsh also reproduces the testimony of a priest named Don Luigi Ferrara, who also saw the apparition. Those who saw the Virgin saw her distinctly enough to be able to identify her with particular portrayals of Mary. The bishop mentions Our Lady of Mount Carmel and Our Lady, the Queen of the Holy Rosary, and the Mother of Sorrows. That they saw her distinctly enough to identify her appearance so exactly, makes it unlikely that this can be attributted to illusion. In addition to seeing Mary, some saw Saint Michael, Saint Anthony, Saint Joseph, Saint Sebastian, and the face of Jesus. Not everyone present saw an apparition, as the bishop clearly implies when he writes: 'And so great were [the pilgrims'] faith and piety that very many among the pilgrims had the happiness of obtaining their wish [of seeing the Virgin]'. ${ }^{35}$ Walsh also summarises the important investigation of Father Joseph Lais, who was educated in physics and medicine and sub-director of the Vatican Observatory, 'and an eminent "all-round" scientist'. ${ }^{36}$ According to Walsh, Father Lais ruled out 'optical delusion' (meaning, presumably, optical illusion). Lais also spoke to an innkeeper who told him over 700 people had seen apparitions at the sight. Lais also spoke with 'various persons' who saw apparitions. ${ }^{37} \mathrm{His}$ investigation confirms the bishop's findings on the issue of people identifying the apparition with a traditional portrait of Mary. He mentions Our Lady of Dolores and Our Lady of Loreto. It also confirms that not all saw the apparition, for he spoke with at least one woman who had gone but did not see anything. ${ }^{38} \mathrm{We}$ are also told at least two people fainted at the apparition.

Case 5 Marian Apparition: This case is unique in that the collective hallucination/OEE was preceded by an illusion. ${ }^{39}$ The episode took place in the village Tilly-sur-Seulles in Normandy, France, in 1896. In the school Ecole Libre on 18 March 1896, one of the nuns was addressing a group of approximately one hundred girls concerning devotion to Saint Joseph and blessings from Saint Mary. As she was speaking, two girls about age thirteen, said they saw the Virgin Mary

\footnotetext{
34 Walsh, Apparitions, 178-79.

35 Walsh, Apparitions, 178.

36 Walsh, Apparitions, 178.

37 Walsh, Apparitions, 177.

38 Walsh does not, of course, report the entirety of Lais's findings. Thus this should not be taken to indicate Lais encountered only one person who failed to see anything.

39 The following summarises the account in Walsh, Apparitions, 205-217.
} 
outside the window. The nun, along with two other nuns who soon gathered, and the rest of the girls, went to the window and 'one and all' saw the Virgin at a distance of about 1200 yards. ${ }^{40}$ The apparition reappeared several times on the succeeding days, and it is explicitly stated that on a couple of these occasions everyone present did see the phenomena (and there are no indications that at any point some present did not see it). The following event makes it clear that this apparition should be classified as an illusion: in late March, a group of girls along with one of the nuns attempted to get a close up view of the apparition. Another group stayed behind, and agreed that when they saw the first group arrive at the spot where the apparition was standing, someone from the second group would wave a handkerchief. When the first group arrived at the approximate destination, they did not see anything. But, they saw the handkerchief waved by the second group indicating that they were at the exact spot where the apparition was being seen by the second group. The fact that this supposed apparition-which, being surrounded by light and having a cloud of light beneath it, was probably not particularly distinct-was only visible from afar but disappeared upon being approached makes it easy to classify this as an illusion.

Soon thereafter, a fourteen year old girl named Louise Poliniere went into the field where the illusion had been seen, and now saw, up close, the Virgin Mary as Our Lady of Lourdes, and Bernadette kneeling beside her. After this, she began visiting the field alone. But soon hundreds were present on each occasion. The account of this comes from Reverend R. F. Clark, who says the testimonies of witnesses he cites come from the French newspapers that reported on the event, and the testimonies were 'for the most part' eyewitness testimony. ${ }^{41} \mathrm{He}$ also says the curé of the local parish took depositions, but he does not make it clear if anything in his account has been supplemented with information from these depositions, or if everything has been taken from the newspapers. He says that a 'large number' of people claim to have seen an apparition of Mary, though he says 'many of the stories told are unworthy of credit' but there is still 'a sufficient number of reliable witnesses'. ${ }^{42}$ He recounts in particular the testimony

\footnotetext{
40 Walsh, Apparitions, 206-207.

41 Walsh, Apparitions, 211.

42 Walsh, Apparitions, 211.
} 
of Jean Francois Madeleine, M. Boisard, M. Theron, Mme Duvet, each of whom saw Mary, and the child of Mme de Moulinier who saw a figure of white and believed it to be a recently deceased aunt. Clarke relates that not everyone present saw an apparition, specifically saying that no priest who went saw anything. He also relates that those who did see Mary saw her differently, and that other things were seen besides Mary: a chapel and a luminous cloud. In another reference to the event, ${ }^{43}$ which does not cite its sources, 'horrible and altogether disquieting' images are said to have been seen. As with case three, some people are reported to have fainted at the sight. ${ }^{44}$ And Thurston adds that some present 'fell down in convulsions or fits' ${ }^{45}$

Case 6 Marian Apparition: This case is from the report of Rene Laurentin, ${ }^{46}$ who himself spoke with one of the main visionaries, and says the incident was investigated by two doctors. In May 1985, twelve children between eight and ten began to have visions of Mary. The visions were confined to themselves for about a month. However, beginning on 20 July 1985, others began to have visions as well. On that day 2,000 people gathered around the visionaries and saw a luminous red cloud with the message 'I am sending this cloud as a first sign' ${ }^{47}$ It is not stated whether some or all of those present saw this phenomenon. Fifty of the two thousand also claimed to see Mary on the same day. Further visions by those other than the original twelve occurred subsequent to this, but Laurentin is not specific on a few important factors: many of these new visionaries were investigated by the two doctors, but he does not say if these people had their visions while in a group, or alone. The doctors determined that some of the visions were a result of a chain reaction brought about by excitement, but we are not told how they arrived at this conclusion. Quite a number of the visionaries renounced their visions after being brought to 'a more realistic, humble, and prayerful realisation of their situation' ${ }^{48}$ But we are not told any reason why some renounced their vision: whether they admitted to lying, concluded they had been hallucinating,

43 Thurston, 'Limpias', 538.

44 Walsh, Apparitions, 216.

45 Thurston, 'Limpias', 538.

46 The following summarises the account in Rene Laurentin, The Apparitions of the Blessed Virgin Mary Today (Dublin: Veritas, 1991): 90-95.

47 Laurentin, Apparitions, 91.

48 Laurentin, Apparitions, 94. 
renounced their visions because they differed from Catholic beliefs, or some other reason.

Other Cases: There are a number of other cases, that I have come across, but which I will not discuss at length either because they are not as well documented as the cases above, or because it does not seem possible to definitely rule out illusion. However, I will mention some of them here for the sake of thoroughness.

Patrick Walker refers to stories of both collective visionary and collective auditory events, as well as the spontaneous appearance of graves, which he had been told about, but he does not mention having spoken to any eyewitnesses. ${ }^{49}$

In Limpias, Spain in 1919, a corpus of Christ on a large crucifix was seen on numerous occasions to make varied movements such as: moving its eyes back and forth, moving its eyes upward, opening and closing its eyes, and moving its lips. ${ }^{50}$ These different actions were seen by different people. This case illustrates the difficulty in differentiating between a hallucination and an illusion. Although this type of movement is quite impressive, it does not seem we can say with certainty that anything beyond illusion took place. ${ }^{51}$ In all of 1919 , approximately 110,000 people went to the church and nine or ten percent of them saw the crucifix move in one way or another. ${ }^{52}$

These same sorts of abnormal occurrences also occurred with a crucifix in Piedramillera, Spain in 1920.53 It is noteworthy that visionaries at both the Limpias and Piedramillera events fainted, just as in the Marian apparitions described above. ${ }^{54}$

A more spectacular occurrence at Limpias at about the same time supposedly involved pictures of saints moving to such an extent that the saints are said to have actually stepped out of their panels. But for

49 Walker, Biographia, 29-32.

50 Christian, Crucifixes, 37-81.

51 An influential sceptic at the time, Luis Urbano, witnessed forty of these visions and ascribed them to optical illusion (Christian, Crucifixes, 78).

52 Christian, Crucifixes, 63. Christian elsewhere says (p. 59) that 3,000 or approximately $7 \%$ of those who came to see the statue during its first four months saw it move.

53 Christian, Crucifixes, 120-40.

54 Christian, Crucifixes, 129-30. 
this, I have encountered only a very brief treatment which gives no further references. .5

Thomas Aquinas refers to eucharistic miracles very similar to case three in which different people beheld different miraculous changes in the Eucharist. ${ }^{56}$

'Many' among thousands who gathered where Mary was supposedly appearing in a fissure in the rocks (note the similarity to case three) are said to have seen her. For this we have just a passing reference which cites no sources, and does not give enough information to rule out illusion, or even legend. ${ }^{57}$

In Lubbock, Texas, in 1990, 'some' in a crowd saw different phenomena: some Jesus, some Mary, some the gates of heaven, among other things, after staring at the sun. ${ }^{58}$ Although it is obvious that staring at the sun is rife for optical illusion, it is difficult to gauge the limits of optical illusion. That is, it is difficult to determine whether staring at the sun could result in such a vision for someone in a normal state of mind (and thus should be reckoned an illusion) or whether such visions are beyond what can be attributed to the normal effects of staring at the sun (and thus should be reckoned a hallucination or OEE).

Herbert Thurston refers to a case where statements were taken 'on oath', of a statue at Rimni which different people saw making different movements, and to cases of moving statues at Rome and Campocavallo where not all present saw the phenomena. ${ }^{59}$

Acts of Peter 7:21, describes a visionary event supposedly led by Peter, in which different people saw Jesus in different ways: some as a boy, some as a young man, and some as an old man. Although the account obviously does not reflect an actual event in Peter's life, it may well reflect visionary experiences which were known to the author of Acts of Peter.

55 Leonard Zusne and Warren H. Jones, Anomalistic Psychology: A Study of Extraordinary Phenomena of Behavior and Experience (Hillsdale, New Jersey: Associates, 1982): 136.

56 Thurston, 'Limpias', 540.

57 George Barton Cutten, The Psychological Phenomena of Christianity (New York: Charles Scribner's Sons, 1908): 65-66.

58 Joe Nickell, Looking for a Miracle: Weeping Icons, Relics, Stigmata, and Healing Cures (Amherst, New York: Prometheus, 1993): 194-95.

59 Thurston, 'Limpias', 533-34. 


\subsection{Analysis}

The above evidence establishes that the fact of group appearances does not place the resurrection appearances in a particularly unique category. Rather, other group religious visions have occurred throughout history. However, it would betray a naturalistic bias to assume that the group religious visions related above are hallucinatory. Evidence must be presented as to whether such visions have a subjective or objective origin. The following characteristics speak strongly in favour of a subjective origin:

The Visions Are Expected: None of the cases that I have examined affirms that a group vision took place spontaneously. We have no cases, for example, of a group of people walking down the street and, entirely unexpectedly, seeing an appearance of the Virgin Mary. Rather, in every case the group assembles already expecting a supernatural occurrence to take place. This indicates that expectation is a causal factor for these events. If expectation plays no role, the number of group visions preceded by expectation ought to be commensurate with that expected by chance. Instead, it appears that all such visions are preceded by expectation. This certainly suggests expectation is a necessary prerequisite for these occurrences.

Extreme Stress: It is noteworthy, that in at least cases 4 and 5, and at Limpias and Piedramillera, people are reported to have fainted at the apparition. In case 4, only two people are reported to have done so, while the other three cases ( 5 and the Limpias and Piedramillera cases) indicate fainting was a regular occurrence for those events. This is important because fainting is a strong indication of extreme stress (of course, fainting is not necessitated by extreme stress, and so we should not conclude that because others at these apparitions did not faint, therefore they did not experience extreme stress as well). The significance of this is that extreme stress is a documented cause of hallucinations, at least in individual cases. ${ }^{60}$ If extreme stress can cause hallucinations when occurring to people alone, there seems no reason why it should not do the same for people in groups. ${ }^{61}$

60 See G. Asaad and B. Shapiro, 'Hallucinations: Theoretical and Clinical Overview', American Journal of Psychiatry 143 (1986): 1088-97; R. K. Siegel, 'Hostage Hallucinations: Visual Imagery Induced by Isolation and Life-threatening Stress', Journal of Nervous and Mental Disease 172 (1984): 264-72.

61 In addition to the fainting, a few other indicators of extreme stress should also be noted. First, in Case 5 many were reported to have fallen into convulsions and fits (see 
Not Everyone Sees the Vision: It is significant that not all present see the vision. The only cases which give numerical estimates are Patrick Walker's, in which approximately two-thirds (67\%) of those present saw the vision, while the rest did not see anything; and case 6 , in which fifty of two thousand $(2.5 \%)$ saw the vision. ${ }^{62}$ The other cases do not quantify. ${ }^{63}$ Thus, it does not seem possible to determine a standard ratio, and that the percentages should vary from two point five to sixtyseven percent is perplexing. What is important for the present discussion is that not everybody seeing the vision is more consistent with a hallucination than an OEE. Given the rarity of hallucinations, the odds that everyone in a large group of people would be in the proper frame of mind for a hallucination is certainly low. This is particularly true if extreme stress is a cause of collective hallucinations, because while some individuals have hallucinations under extreme stress, obviously all do not. If a random sample of people under extreme stress were placed in a group, we would expect some to hallucinate and some not to. And so, if simultaneous hallucinations did occur, it is to be expected that there would be some present who would not be in the necessary frame of mind. By contrast, there seems no reason why an OEE should refuse to make itself visible to all present. While it has no obligation to appear to everyone, in not doing so, it acts exactly as a hallucination would.

Those Who Do See the Vision See It Differently: This is explicitly noted in cases 1, 3, 4, and 5, and in a number of the other cases. In case 1 , Walker mentions a wide variety of different things being seen. In case 3, different miracles were seen in the Eucharist: some seeing only the child Jesus, some Jesus with his heart bleeding, some Jesus holding his hand to stop the bleeding, others the monstrance illuminated. In case 4, Mary was clearly seen differently by different people as she was said to resemble different portrayals of Mary according to different pilgrims (Our Lady of Mount Carmel and Our Lady, the Queen of the

above). Second, the priest at the Piedramillera church stated that the majority of seers, after seeing a vision: 'for a good while cannot talk, only weep, with a hiccup that lasts a long time' (Christian, Crucifixes, 131). And, while not giving any specifics, Patrick Walker (Biographia, 33) says there was 'a Fear and Trembling upon these that did see [the vision]'.

62 There is also Piedramillera, which estimates 9-10\% (see above), but as mentioned earlier this may be an illusion not a hallucination.

63 Though at least the general tone of the Melleha report suggests the phenomenon was seen by the majority. 
Holy Rosary, and the Mother of Sorrows, and so on). Others saw Saint Michael, Saint Anthony, Saint Joseph, Saint Sebastian, or the face of Jesus, rather than Mary. In case 5, not only was Mary seen differently, but a chapel and luminous cloud, together with 'horrible and disquieting' images were seen. Although cases 2 and 6 do not specifically state that this aspect applied to these cases, neither do they deny it. This phenomenon of different people seeing different things is what one would expect if the visions are hallucinations. This is because different people, gathering to see a vision, would certainly have different expectations of the particulars of that vision. ${ }^{64}$ For example, in a Marian apparition, we would expect that, for example, those familiar with images of Mary as Our Lady of Mount Carmel will have this picture in their minds as they anticipate her appearance. In contrast, those familiar with images of Mary as the Queen of the Holy Rosary will have this picture in their minds, and so on with different people who are familiar with different portrayals of Mary. If then we should have an event, where many of these people suddenly project subjective visions of Mary, we should expect that each would project her according to how he or she is accustomed to picturing her. Thus, a collective hallucination of Mary would virtually demand that some, for example, would see Mary as Our Lady of Mount Carmel, some as the Queen of the Holy Rosary, and so on. By contrast, if an OEE actually occurs, whatever force causes apparitions of Mary ought to have the means to cause everyone to see Mary identically. In not doing so, it is again acting as a hallucination would.

The Vision Never Carries on a Conversation: It is also significant that in no case does the vision ever carry on a conversation with the recipients. This is important because a group conversation would be impossible if the vision was a hallucination. We have mentioned the fact that expectation is the operant factor in determining the content of a hallucination. But while expectation seems theoretically capable of accounting for collective visual hallucinations, it would not be able to give rise to a collective hallucinatory conversation. This is because, while a group of people could go expecting to see Mary, or even go expecting to hear a short statement from Mary (e.g. 'I am the queen of the Rosary'), they could not possibly go with an entire conversation planned out in their mind. Thus, an apparition of Mary or other OEE

64 For further discussion on the role of expectation in hallucinations, see below. 
which carries on a group conversation would thereby prove itself to be no hallucination. However, none of the above cases involve a group conversation. ${ }^{65}$ This is another indicator of the hallucinatory character of these visions.

\section{Jesus' Resurrection Appearances}

The existence of the well-documented cases above necessitates the conclusion that religiously inspired collective hallucinations can and do occur. The significance of that fact is twofold. First, the recognition that group hallucinations do take place refutes the argument that the resurrection appearances cannot be hallucinations because some of the appearances occurred to groups. Second, that actual examples of group hallucinations are now available to examine, means that the question of whether or not the group resurrection appearances should be considered hallucinations largely depends on whether the appearances can be shown to be similar to, or different from, these collective hallucinations. By examining the cases above, we can deduce what the resurrection appearances would have looked like if the hallucination hypothesis is correct. The group appearances (although not necessarily the individual appearances): 1) would have been expected; 2) would probably have involved some external signs of extreme stress (e.g.

65 Although, one naturally wonders about the numerous cases of Marian apparitions, such as those at La Sallete, Fatima, and Medugorje, where, though the apparition does not carry on a conversation with the entire crowd, it does carry on a conversation with a small group of seers. Because of the group conversations, hallucinations seem to be precluded as an explanation for these events. Should they then be regarded as OEEs? I am highly sceptical, for, based on what is known of the case of the Garabandal visionaries, I think it is difficult if not impossible to rule out fraud in all of these cases. In the Garabandal case, three girls who were supposedly receiving messages from Mary, were tested in a similar manner to that of the Medugorje seers: e.g. they were prodded with needles and did not react to being picked up and dropped (Lisa J. Schwebel, Apparitions, Healings, and Weeping Madonnas: Christianity and the Paranormal [New York: Paulist, 2004]: 86). These tests would seem to be difficult to fake and would thus seem to vindicate the seers' honesty. However, one of the three girls eventually admitted to faking the vision (Nickell, Looking, 184). This makes it virtually certain that the event was a fraud, for why would someone who took part in a real Marian apparition renounce it? Yet, the other two girls continued to maintain that the apparition was real, and they still have a following to this day (Schwebel, Apparitions, 35). Since the Garabandal event was clearly a hoax, and since Fatima, Medugorje, and others have produced no evidence beyond what was produced by the Garabandal seers, it seems fraud is a plausible natural explanation for all of these events. 
fainting); 3) would have involved Jesus being seen only by some members of the group; 4) would have involved Jesus being seen differently by those who did see him; 5) would not have involved Jesus conducting group conversations. It is clear that in their present form the resurrection narratives do not characterise the appearances in these ways. In the resurrection narratives, Jesus' appearances are not typically expected, there is little to indicate extreme stress, there is no indication that not everyone saw Jesus nor that different people saw him differently, and Jesus often conducts group conversations. However, since there is significant disagreement among scholars regarding the historical reliability of the resurrection narratives, the mere fact that the narratives are inconsistent with collective hallucinations is unlikely to convince many that the original appearances were likewise inconsistent with collective hallucinations. In contrast to the Gospel narratives, the information related by Paul in 1 Corinthians 15:3-8 - that there were appearances to Peter, the twelve, the five hundred, James, all the apostles, and Paul-is nearly universally acknowledged as historical. ${ }^{66}$ Yet, the material of 1 Corinthians 15:3-8, in and of itself, would seem to be consistent with the hallucination hypothesis: the fact of group appearances is consistent with hallucinations, and that Paul only lists the appearances without narrating them, leaves open the possibility that the appearances were of the same nature as the collective hallucinations examined above. However, a strong argument can be made against considering the appearances as examples of collective hallucinations, quite apart from the question of the overall reliability of the Gospel narratives. ${ }^{67}$ This

66 On the reliability of this material, see again, Craig, Assessing, 3-62. I do take for granted that the appearances which are only listed by Paul in 1 Cor. 15:3-8, were normally narrated in full. Contra Ulrich Wilkens (Resurrection: Biblical Testimony to the Resurrection: An Historical Examination and Explanation [Atlanta: John Knox, 1978]: 63) it is highly unlikely that any potential convert would accept the truth of the resurrection based on hearing only, for example, 'Jesus appeared to Peter'. Rather, anyone hearing such a statement would immediately wonder what it meant, at which point Paul, or whoever was relating the appearances, would need to elaborate.

67 By considering the potential historicity of Jesus' resurrection, I obviously assume the possibility of giving historical evidence for a miraculous event. One of the most important resources on the topic of miracles from the traditional theistic perspective is Douglas R. Geivett, ed., In Defense of Miracles: A Comprehensive Case for God's Action in History (Downers Grove, Illinois: Intervarsity, 1997). See also chapter 14 of Norman L. Geisler, Christian Apologetics (Grand Rapids, Michigan: Baker, 1976), with particular attention to the arguments of David Hume on pp. 265-67, 275-76. On how the questions surrounding miracles relate to Jesus' resurrection, in particular, see Davis, Risen, 1-21. I note that in the issue of the Journal for the Study of the Historical 
argument is largely dependent on the role that expectation plays in creating a hallucination. Thus before proceeding, it is necessary to address how a person's expectations affect his or her hallucination.

The notion that hallucinations do not provide an adequate explanation for the resurrection appearances because the appearances did not conform to the disciples' expectations has been suggested before by both William Lane Craig and James Dunn. ${ }^{68}$ Craig argues that because first-century Jews expected the resurrection to be a communal event which occurred at the end of the age, whereas Jesus' resurrection occurred singularly and before the end of the age, the resurrection does not conform to the disciples' expectations and so cannot be hallucinatory. ${ }^{69}$ Craig suggests that if the disciples had seen appearances of Jesus after his death, they would have concluded not that he had been resurrected, but rather that his spirit had been exalted to heaven, because this idea would better conform to their expectations. Craig is probably wrong in his assessment that a resurrection of a single individual within history is necessarily incongruous with the disciples' expectations. Mark 6:14 and Matthew 16:14 indicate that some during Jesus' ministry thought Jesus was the resurrected John the Baptist or the resurrected Jeremiah, thus requiring that John or Jeremiah had been raised before all others. ${ }^{70}$ However, Craig's premise

Jesus vol. 3, issue 2 (2005) which was devoted to N.T. Wright's The Resurrection of the Son of God (Minneapolis: Fortress, 2003) as well as in the various book reviews of Wright's book, there has been little attempt to refute the thesis of the book a priori by appealing to the impossibility of the miraculous.

68 For the sake of simplicity, and following scholarly convention, I sometimes refer to those present at the resurrection appearances as 'disciples', even though one can argue that this is not strictly accurate: Paul was a sceptic before his appearance, John reports that James was sceptical of Jesus prior to Jesus' death (John 7:5), and the appearance to the 500 may have involved non-believers (a gathering that large likely would have caused curious onlookers to wander in).

69 Craig, Assessing, 290, 297-304

70 Even N. T. Wright, who devotes the majority of his book to giving an extensive argument that the disciples' belief in the singular resurrection of Jesus was discordant with the Jewish expectation of the resurrection as a communal event at the end of the age, admits that if Herod really said something to the effect that Jesus was the resurrected John the Baptist (which Wright thinks possible) "it seems to be an exception to the general rule, that "the resurrection of the dead" would happen to all the righteous simultaneously, not to one or two here and there' (Resurrection, 413). Although Wright then says that we should not 'regard Herod and his court as the most accurate indicators of mainstream second-Temple Jewish belief' the fact is still detrimental to his thesis that the disciples' belief in the singular resurrection of Jesus was a novel, unusual concept wholly discordant with second Temple Jewish thinking. If there were 'non-mainstream' Jews entertaining the notion of a singular resurrection 
is correct: people do hallucinate in accordance with expectation. This is true almost by definition, because a hallucination, as a projection of the mind cannot contain anything not already in the mind. Thus, for example, if Catholic pilgrims who gather for a Marian apparition hallucinate, they will probably hallucinate Mary, because that is what they are expecting to see. If they hallucinate something else it will be something which is still compatible with their expectations as Catholic pilgrims, for example a hallucination of Jesus, or Joseph. But they will not hallucinate something which is wholly contrary to their expectations such as a hallucination of Muhammed or Buddha. ${ }^{71}$

Granting, then, that hallucinations do accord with the hallucinator's expectations, in order for us to determine the expectations of the disciples at the resurrection appearances, we must first address how it is possible to determine a hallucinator's expectations. There are two factors which determine a person's expectations. First, the person's general cultural milieu, and second, events peculiar to their particular lives. As an example, consider case 4, of Bojano Italy, where Mary was seen as Our Lady of Mount Carmel and Our Lady, the Queen of the Holy Rosary, and the Mother of Sorrows, among others. If we were to investigate portrayals of Mary from Bojano in 1888-pictures, paintings, icons and so on-we would surely find these different portrayals of Mary reflected in them. ${ }^{72}$ And we would find that, for example, those who hallucinated Mary as Our Lady of Mount Carmel

during Jesus' lifetime, then the disciples' belief in Jesus' resurrection does not seem as unique as Wright portrays it.

71 It is worth noting that Near Death Experiences, at least many of which are likely hallucinatory, illustrate how cultural influences affect hallucinations. Keith Augustine ('Hallucinatory Near-Death Experiences', <http://www.infidels.org/library/modern/ keith_augustine/HNDEs.html\#cultural\%20differences> [accessed 26 September 2007]) documents how near-death experiences differ depending on the person's culture. For example, in Christian cultures, Christian images are typically seen during NDEs, whereas in Hindu countries Hindu imagery is usually seen, while Japanese experiencers often see images typical of Japanese art.

72 In the same vein, William Christian Jr suggests that the Marian visionaries at Piedramillera interpretations of Christ's face on the crucifix were conditioned by the idiosyncrasies of their religious upbringing (Crucifixes, 132). This idea also accounts for the frequent observation that a Marian apparition's ethnicity varies according to the ethnicity of the recipient. She appears English to an English person, Hispanic to a Hispanic person and so forth. It is also worth noting that Michael P. Carrol (Cult of the Virgin Mary [Princeton, New Jersey: Princeton University, 1986]: 148-94) provides many intriguing suggestions as to how Marian seers' visions were influenced by their culture and personal experiences (see esp. his treatment of the Lourdes case, 156-65). Although I am not, like Carrol, a Freudianist, most of his suggestions in this regard are not necessarily tied to Freudianism. 
had at some point in their lives seen a portrayal of Mary to this effect. These two factors are not confined to determining hallucinations, rather cultural milieu and the events particular to a person's own life are what determine what anybody will think about anything. It is because they undergird our thinking, and hallucinations are a projection of thought, that they are the two factors which influence hallucinations. William Lane Craig appeals to general cultural milieu in his argument that the disciples would not hallucinate a resurrected Jesus because an individual resurrection before the endtime was contrary to Jewish thought. James Dunn appeals to the events particular to the disciples' lives when he suggests that Jesus' predictions of the Son of Man coming on the clouds of glory should have caused the disciples to hallucinate Jesus on the clouds of heaven. ${ }^{73}$

Alongside Craig and Dunn, I argue that the resurrection appearances should not be regarded as hallucinations, because they differed from the disciples' expectations. However, my argument is considerably more complex than either of theirs (although my argument entails Dunn's to a certain extent) and runs as follows. First, I add to Craig and Dunn's observation that expectation affects hallucinations, the point that in collective hallucinations different people see different things. I believe there is strong reason to suppose that many (though not all) of those at the resurrection appearances would have expected Jesus to appear in a glorious form. ${ }^{74}$ Because people hallucinate in accordance with expectation, those who came to the group resurrection appearances expecting to see Jesus gloriously would have seen him as such. Thus, if the group resurrection appearances were collective hallucinations, then, analogous to the collective Marian apparition in Bojano Italy where some people saw Mary as Queen of the Holy

73 James D. G. Dunn, The Evidence for Jesus (Louisville, Kansas: Westminster, 1985): 72, "If we pursue the logic of the "hallucinatory projection" explanation, we would expect the hallucinations to be made up of images and symbols the first disciples had gleaned from Jesus. Of these, the image with greatest potential power to fire the imaginations of the disappointed disciples would probably be the one of a heavenly figure "coming on clouds of glory".'

74 By a glorious appearance, I mean any appearance which would be considered spectacularly impressive, majestic, splendid, or the like. For example, appearing as a bright light (as Jesus does in Acts 9:3), appearing surrounded by light (God in Ezek. 1), appearing in dazzling clothes (Matt. 17:2), appearing like an angel, appearing in royal garb (Jos. Asen. 6:5), appearing exceedingly beautiful (Jos. Asen. 18:7-11), an appearance which causes everyone to fall as if dead (the guards in Matt. 28:4), or be overcome with awe (Daniel fainting at the appearance of the angel in Dan. 8:18). 
Rosary and others as Our Lady of Sorrows ${ }^{75}$ some people would have hallucinated Jesus as glorious and some as non-glorious. If the group resurrection appearances did involve some people hallucinating Jesus gloriously, then this means that stories of glorious appearances would have been circulating during Christianity's earliest days, when the material of 1 Corinthians 15:3-8 was being formulated. However, it is evident that by the time the Gospels were composed there were no stories of glorious resurrection appearances circulating, for the Gospels present us with decidedly non-glorious appearances; Jesus' appearance is quite mundane and ordinary. ${ }^{76}$ Yet, I believe it can be shown that if the early church had stories of glorious resurrection appearances, it would have desired to preserve them, and hence such stories should, if they ever existed, appear in the Gospels. That the early church did not preserve stories of glorious appearances indicates that such stories were never there to begin with. But if the early church had desired to preserve glorious appearance stories, and glorious appearances would have occurred if the appearances were hallucinatory, then the absence of glorious appearance stories indicates that the appearances were not hallucinatory. ${ }^{77}$

In order for this contention to be valid, two facts need to be established: first, that some of those at the resurrection appearances would have expected Jesus to make a glorious appearance; second, that the early church would have desired to preserve stories of glorious appearances. Five pieces of evidence can be presented in support of the first fact:

75 See above.

76 One might suggest that the appearance of Matt. 28:16-20 in which Jesus declares that all power and glory has been given to him and that he will be with the disciples until the end of the age, presents a glorious Jesus. However this type of 'gloriousness' relates to the authority and status of Jesus. I am speaking of a gloriousness in terms of his physical appearance.

77 Let me thank Dale Allison, Richard Carrier, and the reviewers for Tyndale Bulletin, for their criticisms and suggestions regarding the present argument. There are various other arguments against the hallucination theory besides the one I am presenting here. See Kreeft and Tacelli, Handbook: 186-88; Craig, 'Closing Response: 187-200'; John J. Johnson, 'Were The Resurrection Appearances Hallucinatory? Some Psychiatric and Psychological Considerations', Churchman 115 (2001): 227-38; Habermas, 'Recent Revival'. For criticisms of these arguments see Price, Beyond: 8184; Richard C. Carrier, 'Craig's Empty Tomb and Habermas on Visions', Online: http://www.infidels.org/library/modern/richard_carrier/indef/4e.html (accessed 26 September 2007); Parsons, 'Peter Kreeft'. 


\subsection{General Beliefs about the Resurrection}

Those present at Jesus' appearances were expecting the appearance of a resurrected person. ${ }^{78}$ It is thus quite likely that their expectations of Jesus' appearance would have been influenced by Jewish ideas concerning the resurrection generically. ${ }^{79}$ The available evidence indicates that many Jews in and around the first century expected the resurrected body to be glorious in appearance. ${ }^{80}$

2 Baruch 49-51 contains an explicit discussion of what the resurrected body will look like. In 2 Baruch 49:1-3, Baruch asks whether the resurrected body will still have the 'present form' or if that form will be changed. ${ }^{81}$ The reply (2 Bar. 50:1-4) seems to affirm Baruch's first thought: the resurrected will not be changed, rather their form shall remain the same. However, Baruch is then told that the resurrected having the same form is only a temporary situation; their form is ultimately to be transformed. In 2 Baruch 51:9-11, the shape of the raised is changed. The wicked take a 'more evil' form, while the righteous are 'glorified by transformations'. They are changed into the 'light of their beauty' and 'the splendour of angels'. They will no longer age, and will be equal to the stars and may be changed to any shape they desire, including beauty, loveliness, light, and the splendour of glory. This description certainly presents a glorious resurrected body. 2 Baruch thus presents two different possibilities for the

\footnotetext{
78 It is often said that the disciples had no expectation that Jesus would be resurrected, and the Gospels do present them as not at all having resurrection on their mind when the tomb was found empty (e.g. Luke 24:11 (the disciples did not believe the report of the women); John 20:9 (they did not understand he had to rise from the dead)). But such lack of expectation applies, at best, only to the initial appearance. Once word got out that Jesus was risen, the subsequent appearances would certainly involve the expectation of seeing a resurrected Jesus. The first appearance is reported to have been an individual appearance (whether to Peter or Mary Magdalene), thus all of the group appearances, which are the ones I am considering here because of their possible analogy with the collective visions discussed above, occurred after the first appearance and so those at these appearances expected to see a resurrected Jesus. Thus, when I refer to the disciples' expectations of the resurrection appearances, I am referring to their expectations at the group appearances, subsequent to the initial appearance.

79 This is just what Craig reasons in his argument discussed above.

80 For a survey of resurrection texts in the apocrypha and pseudepigrapha, see Hans Clemens Caesarius Cavallin, Life after Death: Paul's Argument for the Resurrection of the Dead in I Corinthians 15: An Enquiry into the Jewish Background (Lund, Sweden: Gleerup, 1974); Wright, Resurrection, 129-206.

81 All quotations from the pseudepigrapha in this article follow the translations in James H. Charlesworth, ed., The Old Testament Pseudepigrapha (2 vols.; Garden City, New York: Doubleday, 1983-85).
} 
resurrected body: the first expects the resurrected body to appear essentially as it appeared prior to death, with no significant changes and thus not glorious. The other holds that the resurrected body will be changed into a glorious form.

If 2 Baruch provided the only reference to a glorious resurrected body in Second Temple Jewish literature, one might well conclude that the idea of a glorious resurrection was a notion confined to the author and his immediate audience. In that case, there would be little basis for thinking that any of the disciples were familiar with this idea. However, if there are in fact numerous texts from different authors and provinces which present the idea of a glorious resurrection, it becomes increasingly likely that this idea was widespread in Second Temple Judaism, and thus an idea with which the disciples were probably familiar. While 2 Baruch seems to be the only text which explicitly contrasts a glorious versus non-glorious resurrected body, the notion of a glorious resurrected body appears in a number of other texts.

Daniel 12:2 speaks of the wise as shining like the firmament, and those who lead many to righteousness shining like the stars on the day of resurrection. The 'stars' are probably angels, not literal stars and so we have here, as in 2 Baruch, transformation to an angelic-like form. ${ }^{82}$ A shining appearance would count as glorious, whether shining like an angel or like a literal star, and so the earliest undisputed reference to resurrection in the Old Testament can be interpreted as a reference to glorious resurrection. ${ }^{83}$ Along the same lines as Daniel, 1 Enoch 104:2

82 'Stars' frequently refers to personal beings who are either angels or essentially equivalent to angels. Job 38:7, "when the morning stars sang together and all the heavenly beings shouted for joy'. In Judg. 5:20 the stars fight on the side of Israel. Although, 1 Esdras 7:97, mentioning the sun alongside the stars, seems to have in mind literal stars.

83 The question arises as to whether references to the resurrected shining like the stars or the sun, occurring as they do mostly in apocalyptic books, are meant to be taken literally. Two lines of evidence indicate that this is probably what at least some of these texts have in mind. First, 2 Bar. 51:10 attests that a literal understanding of the resurrected having the appearance of 'light' (and so, by implication, shining) definitely existed in first century Judaism. Second, there are numerous references to God, angels, or people shining or appearing bright, or giving off light, etc., which are clearly literal. Jesus' appearance at the transfiguration, wherein he shone like the sun and his clothing became dazzling white (Matt. 17:2) could hardly have terrified Peter as it did, if it was not literal. Nor would Methuselah have fled in fear of the newborn Noah if his body was not literally as white as snow, and his eyes were not actually causing the house to glow like the sun (1 En. 106:1-7). Jesus certainly has the appearance of an actual light 'brighter than the sun' (Acts 26:13) which causes Paul and his companions to fall down. And Aseneth would not have 'been filled with great fear and her limbs 
reads: 'you shall shine like the lights of heaven'. And four verses later 'you are to be partners with the good-hearted people of heaven [i.e. angels]'. 1 Enoch 38:4 says the faces of the resurrected shall be shining so that the wicked will not be able to behold them. According to Wisdom 3:7, the just will shine at the time of their visitation. ${ }^{84}$ PseudoPhilo 33:5 says that if the people imitate their fathers, they will become 'like the stars of heaven'. According to 2 Esdras 7:97 'their face is to shine like the sun' and 'they are to be made like the light of the stars'. So too, 2 Enoch 66:7 (Rec. J): 'for they will be made to shine seven times brighter than the sun'. In addition to the resurrected body being described as shining, some texts claim the resurrected will wear glorious garments. 1 Enoch 62:15-16 speaks of the righteous, who when they rise from the earth, will wear 'garments of glory'. 1QS 4:7-8 assures the just of 'eternal life without end, a crown of glory and a garment of majesty in unending light' ${ }^{85}$ Pseudo-Philo 39:2 speaks of Adam eventually sitting on Satan's throne; as Satan is a fallen angel, this may imply transformation to angelic like form. The notion of a shining appearance like that of the 'stars' and the association with angels, together with the 'garments of glory' all amount to the idea of the resurrected body being a transformed, glorious body.

trembled' (Jos. Asen. 14:10) if the face of the angel she saw was not 'like lightning' and his eyes not 'like sunshine'. Apart from this, some sort of glorious appearance seems required if the 'stars' are in fact angels. For I am aware of no view in firstcentury Judaism which sees angels as non-glorious (that is, in their natural state; they may of course adopt a non-glorious appearance as a disguise). John P. Meier, ( $A$ Marginal Jew: Rethinking the Historical Jesus [vol. 3; New York: Doubleday, 2001]: 423), states: 'angels in the Old Testament and early Judaism were thought to have highly rarefied or refined bodies (made e.g. of fire)'. See the references to angels' appearances later in this essay. Thus, the resurrected being transformed into an angeliclike nature would seem to necessitate taking on a glorious appearance.

84 For the understanding of this passage as affirming resurrection see Wright, Resurrection, 162-74.

85 Once again, we encounter the question of whether the resurrected were thought to wear literal glorious garments, or whether this is just a figurative way of describing their redeemed state. What needs to be considered is that in the ancient world, people did wear special clothing particular to their honour status or social rank. See John J. Pilch and Bruce Malina, eds. Handbook of Biblical Social Values (Peabody, MA: Hendrickson, 1993): 21-27. Since resurrection involved a physical body, and that body had to be covered with some sort of clothing, it would be natural for some Jews to think they might be given specially noteworthy garments in reflection of their high honour status as resurrected people. Hence, 1 En. 62:15-16 and 1QS 4:7-8 are probably meant literally. It is often difficult to sort out the literal from the figurative in apocalyptic works. For some pertinent thoughts: Dale C. Allison Jr, Jesus of Nazareth: Millenarian Prophet (Minneapolis: Fortress, 1998): 157-64. 
Texts can, of course, be cited which envision a non-glorious resurrection. 2 Baruch considers non-glorious resurrection possible, and Sibylline Oracles 4:179-92 seems to affirm it. The rabbinic writings are sometimes considered the prime exponents of a physicalist, and thus non-glorious, resurrection. Yet, even here the conception of a glorious resurrection is not totally lacking:

'It was a favorite saying of Rab: "Not like this world is the world to come". In the world to come there is neither eating nor drinking, no procreation of children or business transactions, no envy or hatred or rivalry. But the righteous sit enthroned, their crowns on their heads, and enjoy the radiance of the Shekhinah' ${ }^{86}$

This text clearly conceives of a glorious resurrection, as it describes the resurrected wearing crowns and sitting enthroned. ${ }^{87}$

Moving from general cultural milieu to specific life events, there is also some reason to think that the disciples were exposed to the idea of a glorious resurrection during their time with Jesus. Mark 12:25 records Jesus as saying that the resurrected will neither marry nor be given in marriage, and that they will be like the angels in heaven. This statement may well have been understood by some of the disciples as an affirmation of angelic transformation for the resurrected. Since angels were believed to have glorious bodies, ${ }^{88}$ such an understanding may have caused the disciples to expect a glorious resurrection body.

The notion of glorious resurrection thus occurs in numerous sources, providing good grounds for holding that this expectation was widespread in Second Temple Judaism. It is thus probable that the idea was known to the disciples and thus a potential influence for their expectations of Jesus' appearances.

\subsection{Saints Exalted after Death}

The resurrection appearances of Jesus are unusual in that they ran counter to the general Jewish expectation of resurrection. Resurrection was typically conceived of as a communal event which took place at the end of the age. ${ }^{89}$ The idea that Jesus had been raised prior to the

86 B. Berakot 17a (c. AD 200-300), cited in Alan Segal, Life after Death: A History of the Afterlife in Western Religion (New York: Doubleday, 2004): 624.

87 That there are some texts which affirm a non-glorious resurrection does not affect my argument, because the argument is not that everyone at the appearances would have expected a glorious resurrection, but only that some of them would.

88 See $n .85$ above.

89 Although it does not appear this conception was universal. See above. 
general resurrection would probably have affected the expectations of those present for his appearances. Jesus being resurrected shortly after his death is similar to stories of saints who, while not being resurrected, were exalted to heaven after death. It is likely that some of those at the appearances, believing that Jesus had been resurrected shortly after his death, would think this similar to the exaltation of Old Testament saints after their deaths. Those who made this connection would then expect some correspondence between the resurrected Jesus and the exalted saints. Many of these saints were believed to possess a glorious nature following death: 90

Testament of Job 39-40 relates the bodily assumption of Job's children after their deaths. Job looks into heaven and sees them 'crowned with the splendour of the heavenly one' (40:3). At the end of the book, Job's soul is taken to heaven in a chariot (52:7). Testament of Abraham (Rec. A) 11:4-11 recounts Abraham's trip to heaven in which he sees Adam. Adam is 'wondrous' and 'terrifying', 'adorned in glory', and seated on a golden throne. After that (12:3-13:5), Abraham sees Abel also 'wondrous', 'bright as the sun', 'like unto a son of God', and sitting on a throne serving as judge of souls. In 2 Maccabees. 15:13-16, Jeremiah appears 'distinguished by his grey hair and dignity, and of marvelous majesty and authority'. ${ }^{91}$

\subsection{The Appearances to Paul, Stephen, and John of Patmos}

Acts records that Jesus appeared to Paul as a light, ${ }^{92}$ and that Stephen saw Jesus standing at the right hand of God (7:55). John of Patmos relates his vision of a glorious Jesus in Revelation 1:9-20. If hallucinations were operative in these later appearances, then Paul, Stephen, and John hallucinated a glorious Jesus. If this is so, then it

\footnotetext{
90 One might object that if the Gospels are correct in their reports that some thought Jesus was the resurrected Baptist or Jeremiah, and yet the pre-resurrected Jesus was certainly non-glorious, then this may have conditioned the disciples to expect a nonglorious resurrected Jesus. While it may well be the case that some of the disciples did, on this basis, expect a non-glorious Jesus, it is difficult to argue that the thought processes of all of the disciples operated in this manner. See the discussion below on how collective hallucinations involve different people seeing different things, and how that fact is essential to my argument.

91 Although the deceased Onias, who accompanies Jeremiah in this passage, is not described as glorious.

92 It is possible that rather than seeing Jesus as a light, Paul may have seen Jesus' body within a light, as God is seen in Ezek. 1. Neither interpretation affects the argument, as both are clearly glorious.
} 
seems that others prior to these three should have hallucinated Jesus gloriously as well. For it is difficult to understand why the expectations of over 500 people during the initial resurrection appearances failed to produce a hallucination of a glorious Jesus, but then later hallucinations did produce a glorious Jesus. ${ }^{93}$ Thus if hallucinations are the cause of the resurrection appearances, the occurrence of glorious appearances to Paul, Stephen, and John makes it probable that the earlier appearances involved hallucinations of glorious appearances as well.

\subsection{The Vindication of Jesus}

In seeing Jesus after his death, the disciples were seeing someone who they believed had been vindicated by God as the Messiah. There are four reasons why this belief would probably cause some of the disciples to expect Jesus to appear gloriously. First, because Jesus was believed to be the vindicated Messiah, it would be consistent for him to show some outward sign of the fact that he had been vindicated (such as sitting on a throne or wearing a crown). Second, as James Dunn notes, there are traditions in the Gospels which mention the Son of Man coming on the clouds of heaven, ${ }^{94}$ in addition to which, there are also traditions which envision Jesus enthroned (Matthew 19:28/Luke 22:30). If some form of these sayings is original with Jesus, then some at the appearances may well have had these images in mind at the appearances and so should have hallucinated Jesus enthroned or coming on the clouds of heaven. Third, the transfiguration may have influenced the disciples' expectations. If indeed there is some historicity underlying this account, ${ }^{95}$ then there was an event prior to

93 It does appear that the early church held to a conceptual difference between the earlier appearances, which Paul says came to an end with him (1 Cor. 15:3-8: 'last of all he appeared to me'), and Luke implies ended with the ascension, and later appearances which Paul (2 Cor. 12:8-9) and Luke (Acts 7:56; 9:10,12; 18:9; 22:17-21; 23:11) understand to be an ongoing phenomenon. The conceptual distinction (see Craig, Assessing, 51-52) is that in the earlier appearances ('resurrection appearances', proper) Jesus appears in the external world whereas in the later appearances ('visions') Jesus appears only in the intra-mental world of the recipient(s) of the vision. However, there appears to be no reason why the early Christians would expect purely intramental appearances of Jesus to be glorious if they had not expected the extra-mental appearances to be glorious. Thus, the conceptual difference between the earlier and later appearances does nothing to affect the argument that on the hallucination theory a glorious Jesus in later appearances should entail a glorious Jesus in the earlier appearances.

94 Dunn, Evidence, 72.

95 See W. D. Davies and Dale Allison Jr, A Critical and Exegetical Commentary on the Gospel according to Matthew (vol. 2; Edinburgh: T\&T Clark, 1991): 684-93. Apart 
Jesus' resurrection at which some of the disciples saw him appear luminous. It is possible that some of the disciples would have recalled this event in anticipation of the resurrection appearances, and thus expected a luminous appearance of Jesus. Finally, I draw attention to two recent articles by Crispin H. T. Fletcher-Louis arguing that Jesus' appeals to Psalm 110 and Daniel 7:13 indicate that he proclaimed himself to be a High Priestly Messiah. ${ }^{96}$ If Jesus taught that he was a High Priestly Messiah, then given that the High Priest wore glorious attire (see Exod. 39), some of the disciples may have expected the vindicated Jesus to appear after the manner of the High Priest.

\subsection{Contemporary Visions of Jesus}

Philip Wiebe in his book Visions of Jesus: Direct Encounters from the New Testament to Today (NY: Oxford University Press, 1997), recounts thirty-six modern-day visions of Jesus. In each case, Wiebe himself personally spoke with the visionaries. Wiebe relates that thirteen of the thirty-six visions (36\%) saw Jesus accompanied by radiance. ${ }^{97}$ Thus, modern-day visionaries often see glorious appearances of Jesus. Yet, the visionaries discussed in Wiebe's book were unaware of many of the factors which would have predisposed the disciples to see Jesus gloriously. Prior to their visions of Jesus, they were not familiar with traditions anticipating a glorious resurrection, or traditions of saints appearing gloriously, nor had they personally heard Jesus speak about being enthroned or coming on the clouds of heaven, or personally witnessed the transfiguration. Hence, while there would seem to be less reason to think contemporary visionaries would expect a glorious Jesus than there is to think the disciples would have expected such, a substantial percentage of contemporary visionaries do in fact see a glorious Jesus. That contemporary visionaries see a glorious Jesus despite their having fewer factors than the disciples to influence their expectation in this regard, supports the notion that the disciples too would have expected a glorious Jesus.

from the biblical account, there are numerous reports of people being seen as radiant during modern times. See Carlos Alvarado, 'Observations of Luminous Phenomena around the Human Body: A Review', Journal of the Society for Psychical Research 54 (1987): 38-60.

96 Crispin H. T. Fletcher-Louis, 'Jesus as the High Priestly Messiah: Part 1', JSHJ 4 (2006): 155-75; Crispin H. T. Fletcher-Louis, 'Jesus as the High Priestly Messiah: Part 2', JSHJ 5 (2007): 57-79.

97 See the chart on page 227 of Wiebe's book. 
Thus, there is considerable reason to believe that some of the disciples would have expected Jesus to appear gloriously, and therefore if the appearances were hallucinatory they should have involved Jesus being seen gloriously. I should stress here that the strength of this line of reasoning depends on the fact that in collective hallucinations different people see different things. For each of the factors discussed above, it is possible that a given disciple, or even quite a number of disciples, was not influenced by that factor. For example, one can say that there would be some disciples whose expectations were not influenced by traditions of a glorious resurrection, or that there were some who did not recall Jesus' words about coming on the clouds. And it may well be the case that some of the disciples were not influenced by any of these factors and were disposed to hallucinate a non-glorious Jesus. However, my thesis requires only that some of the disciples expected a glorious Jesus, just as for example, only some of the people at the Marian apparition in Bojano, Italy of 1888 expected Mary to appear as Our Lady of Mount Carmel. ${ }^{98}$ The greater the number of people at the resurrection appearances, the more likely it becomes that some of them were influenced by one or more of the factors discussed above. Thus, while it may be that Peter, for example, was not influenced by any of these factors, it is difficult to suggest that none of the twelve, none of the apostles, ${ }^{99}$ and none of the 500 were influenced by any of them.

It is now clear that there are strong reasons for believing that if Jesus' appearances were hallucinations, many of the disciples would have seen Jesus gloriously. Quite probably, others present would have seen him non-gloriously. This would mean that the earliest stories of the resurrection appearances would relate that some people saw Jesus gloriously and others saw him non-gloriously. Once this occurred, there are three logical outcomes which could have resulted: first, the tradition may have been content to maintain the fact that some had seen Jesus gloriously and others had seen him non-gloriously. Although this would have been contrary to common beliefs about the resurrection, first century Judaism was capable of accommodating diverse views. There is no a priori reason why the early Christians would have felt uncomfortable with the idea that Jesus was seen differently by different

98 See above.

99 Those present at the appearance to 'all the apostles'. 
people. Acts of Peter (7:21) was content with this idea, as were the reporters of the various modern apparitions examined earlier in the article. Second, the tradition may have been altered such that only stories of glorious appearances were related. Third, the tradition may have been altered such that only stories of non-glorious appearances were related. Clearly, neither of the first two possibilities materialised, as the Gospels present us only with non-glorious appearances. There are thus two options: either the appearances were hallucinations - and thus stories of glorious appearances were eliminated in favour of nonglorious ones before the writing of the Gospels-or all of the appearances were originally non-glorious, in which case they were not hallucinations. In other words, the viability of the hallucination theory hinges on the question of whether traditions of glorious appearances were eliminated by traditions of non-glorious appearances. If convincing reasons can be given to indicate that the early church's desire would have been to preserve glorious appearances, the conclusion follows that the appearances were indeed non-glorious and thus not hallucinations. Two facts stand out to indicate that the early church would have desired to preserve glorious appearances: ${ }^{100}$

\section{Glorious Appearances Are Appropriate for the Exalted State of Jesus}

Given the early church's belief in Jesus' exalted status (Messiah, divine, sitting at the right hand of God) we should expect the tradition

\footnotetext{
100 I have not here considered possible arguments for the tradition to eliminate glorious appearances. Prime among them would be James M. Robinson's thesis ('Jesus: From Easter to Valentinus (or the Apostles' Creed)', JBL 101 (1982): 5-37) that the tradition originally related luminous appearances. William Lane Craig gives a very persuasive refutation ('From Easter to Valentinus and the Apostles' Creed Once More: A Critical Examination of James Robinson's Proposed Resurrection Trajectories', JSNT 52 (1993): 19-39 (reprinted in Craig, Assessing, 307-325)). See also Gerald O'Collins, 'Luminous Appearances of the Risen Christ', $C B Q 46$ (1984): 247-54. It should also be noted that a transition from glorious appearances to non-glorious appearances is not the same as a transition from a non-physical body to a physical body. A glorious body is not necessarily a non-physical body (e.g. nobody thinks that because Moses is radiant in Exod. 19:16 he is therefore non-physical. Besides which, 'gloriousness' could include such things as wearing a crown, sitting on a throne, causing people to faint; i.e. things that have nothing to do with the body per se) and so all of the arguments traditionally put forth arguing that an originally non-physical idea of resurrection was changed to a physical one are not automatically relevant to the question considered here.
} 
to be inclined to preserve anything which is seen as more appropriate for Jesus' exalted position as against anything considered less appropriate. There are four reasons for thinking that the early church would have considered a glorious appearance of Jesus more appropriate to his exalted status than a non-glorious one: God, angels, the Son of Man, and the saints of Israel's past are all conceived of as glorious.

God's appearance in Exodus 19:16-19, is accompanied by thunder, lightning, a trumpet blast, and smoke. Ezekiel 1:26-28 pictures God as surrounded by 'fire', 'gleaming amber', and 'splendour'. Daniel 7:9 says God's 'clothing was white as snow, and the hair of his head like pure wool'. In 1 Enoch 14, God is wearing a white gown 'shining more brightly than the sun', and 'whiter than any snow' (14:20-21), and 'the flaming fire was round about him' (14:22). In 2 Enoch 22:1 God's face 'was strong and very glorious and terrible'. Pseudo-Philo 25:3 says the Lord's 'appearance was unbearable flaming fire'. Because God is traditionally portrayed as glorious, Jesus appearing gloriously is what would be expected of someone occupying the place of God. The fact that the early church held to a belief in Jesus' divinity, and that glorious appearances would be appropriate for a divine Jesus, suggests that the tradition would preserve glorious appearances. ${ }^{101}$

As God is conceived of as glorious, so are angels. In Daniel 8:18, Daniel faints at the sight of Gabriel. 1 Enoch 17:1-2 mentions angels with an appearance 'like the flaming fire'. Joseph and Asenath. 14:9 describes an angel whose face was 'like lightning' and his eyes 'like sunshine'. In Testament of Job 3:1 an angel appears as a 'very bright light'. Testament of Abraham 2:4 mentions an angel who is 'bright as the sun and most handsome'. 3 Maccabees. 6:18 describes two angels who are 'clothed in glory and of awe-inspiring appearance'. 1 Enoch. 71:1 mentions angels with faces as white as snow. Since angels occupy a particularly close place to God, just as the early church believed Jesus to do, this is another reason to preserve glorious appearances. This argument can be further strengthened. As mentioned earlier, there are texts which speak of the resurrected becoming like stars or angels. If

101 On the high Christology of the early church see, e.g. Richard Bauckham, God Crucified: Monotheism and Christology in the New Testament (Grand Rapids, Michigan: Eerdmans, 1999); Larry Hurtado, Lord Jesus Christ: Devotion to Jesus in Earliest Christianity (Grand Rapids, Michigan: Eerdmans, 2003); Craig S. Keener, The Gospel of John: A Commentary (vol. 1; Peabody, Massachusetts: Hendrickson, 2003): 298-309. 
the Gospel writers held this view of resurrection and believed Jesus to have become like an angel, this would be a strong motivation to preserve anything associating Jesus with angels. There are four indications that the Gospel writers believed Jesus' resurrection involved transformation to an angelic-like state.

First, the Emmaus story, as mentioned earlier, is clearly reminiscent of hidden angel stories (e.g. Gen. 18, Tobit, Heb. 13:2). This is probably also true for John 21:12, and possibly John 20:11. Nothing resembling hidden angel stories is related of Jesus prior to his death. It is only after his resurrection that we meet accounts portraying him as disguised angels are portrayed. This is plausibly explained by postulating that the Gospel writers believed Jesus' resurrection entailed the adoption of an angelic like nature. ${ }^{102}$

Second, Mark 12:25 has already been mentioned. Although the interpretation is not definite, this passage may also reflect the belief that the resurrected become like angels.

Third, Jesus' ability to appear and disappear (John 20:19; Luke 20:36) is more consistent with Jesus adopting an angelic-like nature than it is with him returning to an unchanged, ordinary nature. The miraculous abilities of Jesus' resurrected body are similar to 2 Enoch. 56:3 where, after having his original body replaced with a new body, specifically described as like that of the angels, Enoch has no need for sleep or food.

Fourth, Jesus' appearance as a light in Acts 9 is similar to Testament of Job 3:1 where an angel appears as a light to Job.

1 Enoch 37-71 may or may not be particularly important, depending on its role in an understanding of Jesus' use of the phrase 'Son of

102 David Catchpole, (Resurrection People: Studies in the Resurrection Narratives of the Gospels [London: Darton, Longman \& Todd, 2000]: 88-91), cites texts which reject the idea that angels can eat, and then argues that Luke has Jesus eating fish (Luke 24:36-42) to refute the impression left by the Emmaus story: that the risen Jesus could be understood as angelic. I reject this for three reasons: first, if the Emmaus story posed such a difficulty for Luke, he probably would have simply omitted it. Second, that angels cannot eat was by no means the universal view, some texts affirm that angels can eat (see the texts cited by Klaus Berger, Die Auferstehung des Propheten und die Erhohung des Menschensohnes [Gottingen: Vanhoeck \& Ruprecht, 1976]: 159, 458). Thus, Jesus' eating fish is not necessarily incompatible with transformation to an angelic-like state. Third, the disciples clearly mistake Jesus for a ghost, not an angel (see e.g. Dale C. Allison Jr, Resurrecting Jesus: The Earliest Christian Tradition and Its Interpreters, [New York: T\&T Clark, 2005]: 289-90), in v. 39, thus the eating of v. 42 should most naturally be taken as attempting to refute the idea that Jesus is a ghost, not the idea that he is angel. 
Man'. It is, of course, controversial whether Jesus knew the traditions underlying the book of Similitudes, and by referring to the Son of Man, had in mind an expected Jewish apocalyptic figure. ${ }^{103}$ If Jesus - or rather for our purposes, the Gospel writers - did indeed know the traditions underlying the Similitudes, it is worth noting that Enoch's Son of Man has a countenance 'full of grace like that of one among the holy angels' (1 En. 46:1-2). Hence, an identification of Jesus with the Enochic Son of Man is a further reason for the Gospels to preserve glorious appearances of Jesus.

Lastly, one of the same factors which would lead many to hallucinate a glorious Jesus would also incline the tradition to preserve a glorious Jesus. This is the fact that heroes of Jewish antiquity were often thought to take on a glorious nature. Since Jesus is the Jewish hero par excellence, the early church would likely expect Jesus to be accorded the same level of honour. Those who received a glorious nature after their death have already been discussed above. Job's children are crowned with splendour, and Job himself arises on a chariot. Adam is wondrous and adorned in glory. Abel serves as judge of souls and is like a son of God. Jeremiah has marvellous majesty and authority. Here we can also note those Jewish heroes who were transformed prior to death: Moses' face becomes radiant in Exodus 34:29-35. Noah takes on angelic form in 1 Enoch. 89:1, 9. Enoch puts on clothes of God's glory and becomes like an angel (2 En. 22:8-10). Joseph becomes like a son of God (Jos. Asen. 6:5) and Aseneth is transformed to heavenly beauty (18:7-11). Zephaniah puts on an angelic garment (Apoc. Zeph. 8:3). Job's daughters are given shimmering robes ( $T$. Job 46:7-9). To these one might also add the texts which seem to indicate the Qumranites believed themselves to be undergoing angelic transformation. ${ }^{104}$

Finally, it is significant that Luke records a glorious appearance of Jesus. At the appearance to Paul, Jesus appears as a light 'brighter than the sun' (Acts 26:12) which overpowers Paul and his companions. Since Luke includes this appearance, this would seem to indicate that

\footnotetext{
103 For discussion, see e.g. Ben Witherington, The Christology of Jesus (Minneapolis: Fortress, 1990): 233-61; James D. G. Dunn, Jesus Remembered (Grand Rapids, Michigan: Eerdmans, 2003): 724-61.

104 See Segal, Life, 303-308. However, I am not sure whether these texts have in mind literal transformation.
} 
he was not opposed to glorious appearances and thus would have included more of them had they been available.

\section{Conclusion}

The popular argument that the resurrection appearances could not have been hallucinations because collective hallucinations are impossible should be abandoned; for an examination of the group religious visions considered above reveals that collective hallucinations, while certainly unusual events, have occurred. However, a consideration of the role that expectation plays in creating a hallucination provides the basis for understanding why the resurrection appearances themselves should not be considered collective hallucinations. Hallucinations must accord with the hallucinator's (or hallucinators') expectations and, as we have seen, many of those at the resurrection appearances would have expected Jesus to make a glorious appearance. Thus if the appearances were hallucinations, glorious appearances of Jesus would have occurred. Because the Gospels present us with purely non-glorious appearances, the appearances could have been hallucinations only if, between the time of Paul's authorship of 1 Corinthians 15:3-8 and the writing of the Gospels, glorious appearances were lost in the process of transmitting traditions. However, the evidence indicates that if stories of glorious appearances ever existed they would have been preserved by the tradition, and the absence of glorious appearances from the Gospel narratives is therefore indicative of the absence of any stories of glorious appearances at any point between AD 30 and 70. Since stories of glorious appearances should have been preserved if the resurrection appearances were hallucinatory, their absence from the Gospel narratives serves as a strong argument against the hallucinatory nature of the appearances. 